\title{
Understanding the Effect of Stepwise Irrigation on Liquid Holdup and Hysteresis Behavior of Unsaturated Ore Heap
}

\author{
Leiming Wang ${ }^{1,2,3,4} \oplus$, Shenghua Yin ${ }^{1,2, *}$ and Bona Deng ${ }^{3}$ \\ 1 Key Laboratory of the Ministry of Education of China for High-Efficient Mining and Safety of Metal Mines, \\ University of Science and Technology Beijing, Beijing 100083, China; ustb_wlm@126.com \\ 2 School of Civil and Resources Engineering, University of Science and Technology Beijing, \\ Beijing 100083, China \\ 3 Key Laboratory of Green Chemical Engineering Process of Ministry, Wuhan Institute of Technology, \\ Wuhan 430205, China; bndeng@126.com \\ 4 Department of Materials Engineering, University of British Columbia, Vancouver, BC V6P 1Z4, Canada \\ * Correspondence: csuysh@126.com; Tel.: +86-13811668481
}

Citation: Wang, L.; Yin, S.; Deng, B. Understanding the Effect of Stepwise Irrigation on Liquid Holdup and Hysteresis Behavior of Unsaturated Ore Heap. Minerals 2021, 11, 1180. https://doi.org/10.3390/ $\min 11111180$

Academic Editor: Luis A. Cisternas

Received: 7 October 2021

Accepted: 22 October 2021

Published: 25 October 2021

Publisher's Note: MDPI stays neutral with regard to jurisdictional claims in published maps and institutional affiliations.

Copyright: (c) 2021 by the authors. Licensee MDPI, Basel, Switzerland. This article is an open access article distributed under the terms and conditions of the Creative Commons Attribution (CC BY) license (https:/ / creativecommons.org/licenses/by/ $4.0 /)$.

\begin{abstract}
Liquid is a crucial medium to contain soluble oxygen, valuable metal ions, and bacteria in unsaturated heap leaching. Liquid retention behavior is the first critical issue to be considered to efficiently extract low-grade minerals or wastes. In this study, the residual liquid holdup of an unsaturated packed bed was quantitatively discussed by liquid holdup $(\theta)$, residual liquid holdup $\left(\theta_{\text {residual }}\right)$, relative liquid holdup $\left(\theta^{\prime}\right)$, and relative porosity $\left(n^{*}\right)$ using the designed measuring device. The detailed liquid holdup and the hysteresis behavior under stepwise irrigation are indicated and discussed herein. The results show that relative porosity of the packed bed was negatively related to particle size, and intra-particle porosity was more developed in the $-4.0+2.0 \mathrm{~mm}$ packed bed. The higher liquid retention of the unsaturated packed bed could be obtained by using stepwise irrigation (incrementally improved from 0.001 to $0.1 \mathrm{~mm} / \mathrm{s}$ ) instead of uniform irrigation $(0.1 \mathrm{~mm} / \mathrm{s})$. It could be explained in that some of the immobile liquid could not flow out of the unsaturated packed bed, and this historical irrigation could have accelerated formation of flow paths. The $\theta$ was sensitive to superficial flow rate (or irrigation rate) in that it obviously increased if a higher superficial flow rate (u) was introduced, however, the $\theta_{\text {residual }}$ was commonly affected by $n^{*}$ and $\theta^{\prime}$. Moreover, the liquid hysteresis easily performed under stepwise irrigation condition, where $\theta$ and $\theta_{\text {residual }}$ were larger at $u$ of the decreasing flow rate stage (DFRS) instead of $u$ of the increasing flow rate stage (IFRS). These findings effectively quantify the liquid retention and the hysteresis behavior of ore heap, and the stepwise irrigation provides potential possibility to adjust liquid retention conditions.
\end{abstract}

Keywords: unsaturated packed bed; liquid holdup; hysteresis behavior; stepwise irrigation; heap leaching; flow behavior

\section{Introduction}

As an environmentally friendly, lower cost, and efficient recycling method of valuable metal resources, the solution mining method has been widely utilized in the recycling of lower grade minerals, mine tailings, and wastes [1-3]. It is commonly recognized that valuable metal ions continuously transfer between the reaction interface and the leaching solution, eventually obtaining pregnant leaching solution (PLS) and metal products [4]. In this leaching procedure, the leachate is regarded as the key medium of bacteria, soluble oxygen, and metallic ions [5-7]. The leachate could mainly include mobile and immobile liquids, and both simultaneously exist in this unsaturated ore heap. The liquid retention performance decisively affects solute transfer and industrial leaching operation [8-11]. Hence, to obtain a desirable leaching efficiency, the first step should be to deeply understand the liquid holdup and the hysteresis behavior in the unsaturated ore heap. 
Relying on the current research findings, liquid retention in ore heaps is difficult to describe or predict, because it is highly affected by irrigation conditions (such as irrigation rate, irrigation methods, etc.) and heap conditions (such as inter-/intra-particle porosity, initial moisture content, etc.). On the one hand, the stratification and the segregation of raw crushed ore feeds [12-14] widely appear in the dumping procedure and heavily affect the flow behavior. In other words, the mobile liquid (shown as preferential flow, etc.) and the immobile liquid (shown as stagnant flow, etc.) co-exist in saturated and unsaturated conditions of industrial heaps [15-17]. In this heap, the fluid flow could be roughly divided into faster preferential flow (mainly driven by gravity) and slower liquid diffusion (mainly driven by capillarity forces). On the other hand, the flow paths are mainly dominated by developed conditions of pore structure, especially in ore heaps with lower porosity. The dual-pore structure includes inter-particle and intra-particle pores co-existing in unsaturated heaps $[18,19]$. Different from the heap packed by drain rocks or glass beads, the intra-particle pores of ore heap are well-developed. Thus, the liquid retention condition is an unresolved obstacle and is more complicated in ore heaps. However, heap irrigation in some industrial operations keep consistent for a long period without any stepwise adjustments, which easily accelerates the appearance of preferential flow, unsaturated leachate regions, heap compaction, and undesirable leaching rate [20].

Some recent studies revealed the possibility that liquid retention of ore heaps could be ameliorated by controlling irrigation rate (or superficial flow rate), heap porosity, initial moisture content, and so on [21]. Advanced scanning and characterizing methods were utilized to quantify these changes of liquid retention features in the unsaturated ore heap, which is mainly limited to transient, short-time conditions [22-24]. For instance, Fagan et al. (2014) evaluated the potential connections between liquid retention and dipper parameters of a bioleaching system using magnetic resonance imaging (MRI); based on MRI, the solute transfer and the liquid spreading with irrigation time were quantified [25]. Besides, the third-generation gamma transmission tomography system [26] and the UV fluorescence [27] were also utilized to reveal liquid spreading in an inter-particle scale [28]. However, even though these mentioned findings broke the study-scale bottleneck, these novel characterized methods are partially limited by their shortcomings such as high cost, transience, etc. Some new and lower cost methods such as stepwise irrigation were gradually applied in the valuable mass recycling, such as free phase light hydrocarbon [29], to obtain a higher recycle rate. In the unsaturated ore packed beds, McBride et al. (2015) explored the potential effect of heap porosity on liquid retention and preferential flow paths, and the results reveal that flexible irrigation could disturb and affect initial flow paths [30]. As a result, in the view of the current unsatisfactory liquid holdup behavior of unsaturated packed beds [31,32], adjusting the irrigation operation could promote the liquid retention and eventually obtain desirable extraction efficiency of ore heaps.

In this paper, the liquid holdup and the hysteresis behavior in an unsaturated ore heap under stepwise irrigation conditions are discussed. The liquid retained in the unsaturated ore packed bed was continuously and directly measured using an electronic balance, and the effect of stepwise irrigation on liquid holdup in the unsaturated packed bed was quantified by liquid holdup value $(\theta)$, residual liquid holdup value $\left(\theta_{\text {residual }}\right)$, and relative porosity $\left(n^{*}\right)$. The liquid hysteresis behavior especially was inferred in the drainage process and discussed under the effects of existing liquid holdup (historical irrigation). These results could provide theoretical support in enhanced recycling of waste or low grade minerals in unsaturated heaps.

\section{Materials and Methods}

\subsection{Ore Samples and Its Pretreatment}

The experimental ores in this study comprised one type of secondary copper sulfides, which were sampled from mines of Chile. Table 1 shows the detailed chemical composition of minerals and gangues obtained by X-ray powder-diffraction analyzer. The original ores were crushed by roller crusher and jaw crusher and further meshed into detailed intervals. 
In this study, four particle size intervals including $-19.0+13.5 \mathrm{~mm},-11.2+9.5 \mathrm{~mm},-8.0$ $+5.6 \mathrm{~mm}$, and $-4.0+2.0 \mathrm{~mm}$ are respectively discussed. Their geometric mean diameters were $16.02 \mathrm{~mm}, 10.32 \mathrm{~mm}, 6.69 \mathrm{~mm}$, and $2.83 \mathrm{~mm}$, correspondingly. In this paper, the particle size distribution of crushed ore feeds is not considered to avoid the negative effect of particle segregation and stratification.

Table 1. Mass fractions of dominant ore minerals and gangues (wt.\%).

\begin{tabular}{cc}
\hline Minerals & Mass Fraction (\%) \\
\hline Chalcopyrite $\left(\mathrm{CuFeS}_{2}\right)$ & 0.6 \\
Pyrite $\left(\mathrm{FeS}_{2}\right)$ & 2.7 \\
Illite $\left(\mathrm{K}_{0.65} \mathrm{Al}_{2.0} \mathrm{Al}_{0.65} \mathrm{Si}_{3.35} \mathrm{O}_{10}(\mathrm{OH})_{2}\right)$ & 18.0 \\
Plagioclase $\left(\mathrm{NaAlSi}_{3} \mathrm{O}_{8}-\mathrm{CaAl}_{2} \mathrm{Si}_{2} \mathrm{O}_{8}\right)$ & 29.2 \\
Quartz $\left(\mathrm{SiO}_{2}\right)$ & 34.5 \\
Others & 15.6 \\
Total & 100 \\
\hline
\end{tabular}

The solid density of the ore sample was $2.56 \mathrm{~g} / \mathrm{cm}^{3}$, and the irrigating liquid density was defined as $1.00 \mathrm{~g} / \mathrm{cm}^{3}$. To avoid the negative clogging effects caused by undesirable immigration of fine particles or powders on flow paths, all ore samples were processed by the following procedures: (1) ore samples were washed with deionized water to remove powders; (2) washed ore samples were totally dried to remove free water attached on ore surfaces in the experimental oven for $24 \mathrm{~h}$; (3) dried ore samples were cooled down in lab conditions of $24 \pm 2{ }^{\circ} \mathrm{C}$ for $0.5 \mathrm{~h}$ before formal stacking and column irrigation.

\subsection{Key Parameters of Liquid Retention}

\subsubsection{Relative Porosity $\left(\mathrm{n}^{*}\right)$}

To quantitatively describe the relationship of particle size and dual-pore structure (co-existence of intra-particle and inter-particle) of the ore packed bed, the relative porosity $\left(n^{*}\right)$ was defined in Equation (1) as the ratio of the intra-particle porosity $\left(\phi_{\text {intra }}, \%\right)$ and the inter-particle porosity $\left(\phi_{\text {inter }}, \%\right.$ ) of the ore packed bed. It obviously indicated that the intraparticle porosity played a dominant role when the $n^{*}$ was over 0.5 . The total/inter-particle porosity could be calculated by dry bulk density and wet bulk density. To better describe the influence of the irrigation process on heap porosity, the gray image and the image processing methods were utilized to describe the newly retained liquid. The proportion of black areas was the sum of the proportion of original ores and the proportion of newly retained liquid. The detailed relative porosity of the ore packed bed is shown in Table 2.

$$
n^{*}=\frac{\phi_{\text {intra }}}{\phi_{\text {inter }}}
$$

Table 2. Experimental design under different irrigation and heap porosity conditions.

\begin{tabular}{|c|c|c|c|c|c|}
\hline $\begin{array}{c}\text { Particle Size } \\
\text { (Geometric Mean } \\
\text { Diameter), mm }\end{array}$ & $\begin{array}{c}-19.0+13.5 \\
(16.02)\end{array}$ & $\begin{array}{c}-19.0+13.5 \\
(16.02)\end{array}$ & $\begin{array}{c}-11.2+9.5 \\
(10.32)\end{array}$ & $-8.0+5.6(6.69)$ & $\begin{array}{l}-4.0+2.0 \\
\quad(2.83)\end{array}$ \\
\hline Relative Porosity & 0.143 & 0.143 & 0.159 & 0.176 & 0.196 \\
\hline Irrigation Method & Uniform & Stepwise & Stepwise & Stepwise & Stepwise \\
\hline $\begin{array}{l}\text { Superficial Flow } \\
\text { Rate, mm/s }\end{array}$ & 0.1 & $0.075 \sim 0.1$ & $0.075 \sim 0.1$ & $0.075 \sim 0.1$ & $0.075 \sim 0.1$ \\
\hline $\begin{array}{l}\text { Moisture Content } \\
\text { of Wetted Bed, \% }\end{array}$ & / & $0 \sim 10$ & $0 \sim 10$ & $0 \sim 10$ & $0 \sim 10$ \\
\hline
\end{tabular}




\subsubsection{Liquid Holdup $(\theta)$ and Residual Liquid Holdup $\left(\theta_{\text {residual }}\right)$}

In the irrigation and the drainage processes, the volume of retained liquid in the packed bed could reach the steady state. In this paper, to quantitatively define the liquid retention features under the different packed conditions, the liquid holdup value $(\theta, \%)$ and the residual liquid holdup value $\left(\theta_{\text {residual }}, \%\right)$ were respectively calculated by Equations (2) and (3). The $\theta$ and the $\theta_{\text {residual }}$ were utilized to describe the continuous changes or the residual steady state of the retained liquid in the unsaturated ore packed bed [33].

$$
\begin{gathered}
\theta=\frac{\int\left(v_{\text {in }}-v_{\text {out }}\right) d t}{V}=\frac{v_{\text {in }} t-m_{\text {out }} / \rho}{V} \\
\theta_{\text {residual }}=\frac{V_{\text {steady }}-\int\left(v_{\text {out }}\right) d t}{V}=\frac{\theta V-m_{\text {out }} / \rho}{V}=1-\frac{m_{\text {out }}}{V \rho}
\end{gathered}
$$

where $v_{\text {in }}$ is flow rate in, $v_{\text {out }}$ is flow rate out, $m_{\text {out }}$ is mass of liquid flow out, and $\rho$ is liquid density.

\subsubsection{Relative Unsaturated Liquid Holdup $\left(\theta^{\prime}\right)$}

Owing to the historical irrigation, there were some immobile liquids still reserved in the intra-particle and the inter-particle that could have affected formation of liquid bridge and flow paths [34]. To further reveal historical wetting conditions caused by stepwise irrigation, the relative unsaturated liquid holdup was defined. The net liquid holdup $\left(\theta_{\text {net }}\right)$ was the total liquid holdup minus the original liquid holdup of the wetted packed bed, as Equation (4) showed. The relative unsaturated liquid holdup $\left(\theta^{\prime}\right)$ was the ratio of net liquid holdup $\left(\theta_{\text {net }}\right)$ and total liquid holdup $(\theta)$ to quantify the contribution of inter- and intraporosity in liquid holdup, as Equation (5) showed, where the $m_{\text {water }}$ is weight of added liquid in the pre-wetting process.

$$
\begin{gathered}
\theta_{\text {net }}=\theta-\frac{m_{\text {water }}}{V}=\frac{\left(V_{\text {in }} t-m_{\text {out }} / \rho\right)-m_{\text {water }}}{V} \\
\theta^{\prime}=\frac{\theta_{\text {net }}}{\theta}=1-\frac{m_{\text {water }}}{V_{\text {in }} t-M_{\text {out }} / \rho}
\end{gathered}
$$

\subsection{Experimental Design and Irrigation Scheme}

To eliminate undesirable differences caused by column diameter, the author made data conversion and obtained superficial flow rates $(0.001,0.005,0.01,0.02,0.05$, and $0.10 \mathrm{~mm} / \mathrm{s}$ ). As Section 2.1 mentioned, four types of crushed ore feeds with different diameters were considered. The geometric mean diameters of crushed ore feeds were calculated as $16.02 \mathrm{~mm}, 10.32 \mathrm{~mm}, 6.69 \mathrm{~mm}$, and $2.83 \mathrm{~mm}$. In the stacking procedure of the ore heap, the crushed ore feeds with different geometric mean diameters were utilized independently.

By controlling the superficial flow rate $(u)$, the stepwise irrigation was proposed to reveal the liquid holdup and the hysteresis behavior in the unsaturated packed ore. Specifically, the stepwise irrigation clearly defined that the irrigation procedure was started using the lowest $u(0.001 \mathrm{~mm} / \mathrm{s})$ and stopped irrigation once liquid holdup $(\theta)$ reached the steady state. Then, the residual liquid holdup $\left(\theta_{\text {residual }}\right)$ was obtained at the liquid drainage process; after that, we restarted the irrigation process using a higher $u(0.005 \mathrm{~mm} / \mathrm{s})$ until the $u$ was up to peak $(0.1 \mathrm{~mm} / \mathrm{s})$. Finally, the irrigation procedure was restarted using a lower $u(0.05 \mathrm{~mm} / \mathrm{s})$ until it reached the lowest value $(0.001 \mathrm{~mm} / \mathrm{s})$.

During the irrigation and the drainage processes, the liquid holdup was measured per $15 \mathrm{~s}$, and the residual steady state was confirmed if the residual liquid holdup was continuously unchanged for $15 \mathrm{~min}$. The detailed experimental scheme under different dual-pore conditions is shown in Table 2.

The dual-pore condition of the unsaturated packed bed was described by relative porosity $\left(n^{*}, \%\right)$. Similar to the results of Zhang et al. (2018), it was clear that ore particle 
size was negatively proportional to relative porosity of the ore packed bed [35]. Thus, intra-particle porosity was more developed in the packed bed stacked by fine particles. Besides, to further reveal the effect of wetting conditions caused by stepwise irrigation on liquid retention, five types of the initial moisture content $(0 \%, 1 \%, 3 \%, 5 \%$, and $10 \%)$ of the unsaturated packed bed were selected. The wetting condition was prepared by thoroughly and uniformly mixing deionized water and dry ores in hydrophobic plastic bags before the stacking process.

\subsection{Analytical Apparatus and Device}

The liquid retention and the hysteresis behavior of the unsaturated ore packed bed can be mainly quantified by two methods [36]: (1) directly measuring the weight changes of liquid retention (used in this study); (2) indirectly calculating the flux differences of flow in and out. These two methods are in good agreement, and the former is easier to implement.

Figure 1 shows the structural composition of irrigation experimental device utilized in this paper, which could be mainly divided into three parts:

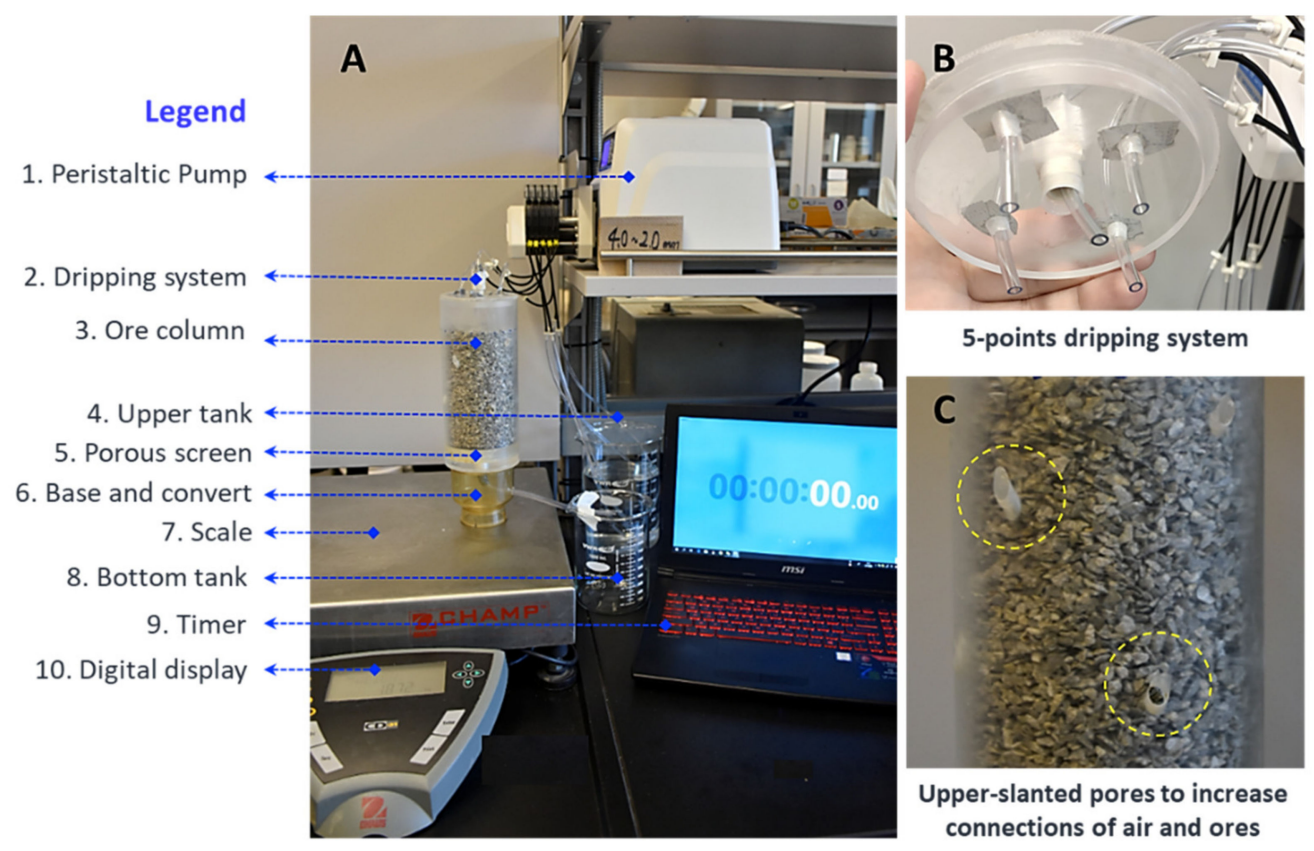

Figure 1. Experimental setup of stepwise liquid irrigation tests. (A): liquid holdup rate real-time characterization test bench; (B): 5 points dripping; (C): upper-slanted pores to eliminate pressure differences.

(1) Irrigation and column system: This included a liquid peristaltic pump $(8 \mathrm{CH} / 4 \mathrm{RL}$ Cole-Parmer, Montréal, QC, Canada), a hydrophobic plexiglass column (height was $150 \mathrm{~mm}$, inner diameter was $90 \mathrm{~mm}$ ) with upper-slanted holes (to eliminate the pressure differences in and out of the packed bed), a 5 point dripper (diameter of each tube was $3.5 \mathrm{~mm}$ to improve the irrigation uniformity and decrease the negative effects of segregated/stratified stacking on flow paths formation), and upper/bottom tanks (replaceable, maximum storage range was $2000 \mathrm{~mL}$ for each).

(2) Measuring system: This included electronic balance (Ohaus, Parsippany, NJ, USA); its sensitivity was $1 \mathrm{~g}$, and the measuring range was $2000 \mathrm{~g}$. This balance could continuously detect the changes of the column system due to the liquid injection and spreading in the unsaturated heaps.

(3) Recording and timer system: This mainly consisted of data storage and test laptop. Based on this device, the residual retained liquid of different ore packed beds could be continuously measured. The experimental data were carefully processed by the OriginPro 
2016 64bt (OriginLab, Northampton, MA, USA), and gray image processing and porosity were calculated via MATLAB R2019b (The MathWorks, Inc., Natick, MA, USA).

\section{Results and Discussion}

\subsection{Liquid Spreading Performance in the Irrigation and Drainage Procedure}

It well known that liquid spreading in unsaturated ore heaps is basically divided into two existential statuses [27,37]: (1) preferential flow mainly exists in the macro-porous flow channels, which is driven by gravity forces and rapidly appears if the liquid breaks through the dry ore heap; (2) diffusion flow mainly exists in micro-porous flow channels, which is driven by capillary forces and slowly appears if the solute transfer and the liquid bridge are well developed. To better understand the effects of irrigation and drainage processes, liquid spreading evolutions (Figure 2A), liquid holdup, and corresponding porosity changes (Figure 2B) at a consistent $u$ were discussed.
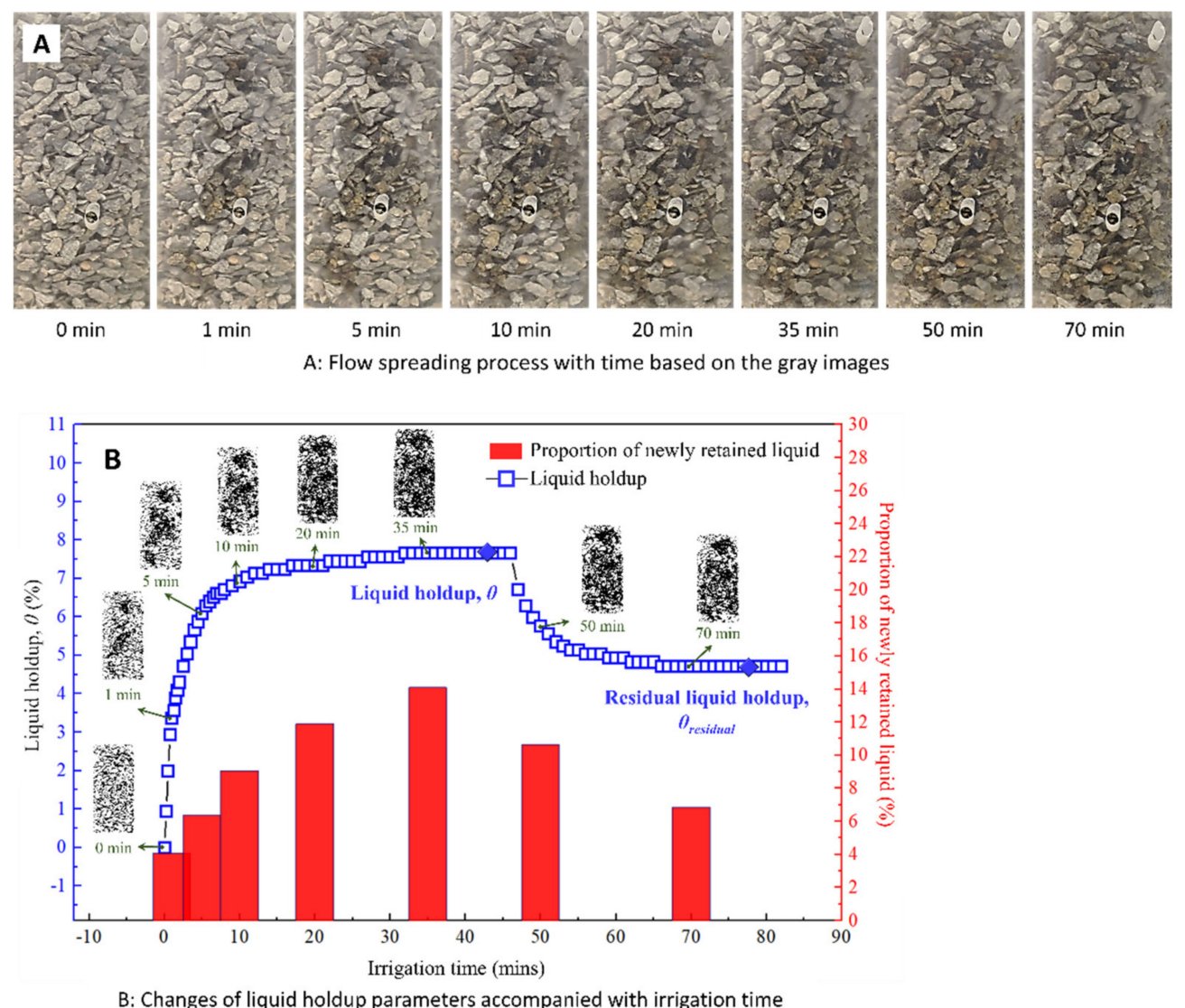

Figure 2. Liquid spreading process with irrigation time (A), quantification of liquid holdup and cross-section porosity in unsaturated ore packed bed (B).

It is clearly revealed by Figure 2A that crushed ore feeds in the column were gradually wetted accompanied by the liquid spreading process. This liquid spreading process could be explained via the key time notes that the liquid (leachate) longitudinally transferred, which broke through and rapidly flowed out of the ore heaps at $5 \mathrm{~min}$; in other words, the preferential flow paths or channels tended to quickly form once the irrigation started. At 5-20 min, the increase rate of liquid holdup was significantly reduced. This indicates that the liquid gradually diffused and spread in the micro-scope pores/voids (also regarded as potential flow paths). In other word, the flow paths/channels gradually reached steady state, and the total liquid holdup tended to reach the peak value. In the 30-45 min period, the liquid holdup value roughly kept consistent, and the liquid retention of ore heaps reached the steady state. In the drainage process (after $50 \mathrm{~min}$ ), the liquid holdup value $(\theta)$ 
rapidly decreased once the irrigation operation stopped, and the $\theta$ gradually reached the residual liquid holdup at $70 \mathrm{~min}$.

To further quantitively characterize this liquid spreading in irrigation and drainage processes, the liquid holdup and the proportion of newly retained liquid were calculated (Figure 2B). This showed that liquid holdup rapidly increased in the first $10 \mathrm{~min}$ and gradually reached the steady state liquid holdup $(7.65 \%)$ at $31 \mathrm{~min}$. This steady liquid holdup indicates that flow paths and immobile liquid (stagnant liquid regions) in the unsaturated ore heap reached the stable state [38]. At the steady state status of liquid holdup, the liquid holdup of the unsaturated ore heap could not fundamentally be improved if the heap porosity and the irrigation condition were consistent. In the drainage process, the liquid holdup decreased from $7.65 \%(\theta)$ to $4.72 \%\left(\theta_{\text {residual }}\right)$. In other words, the residual liquid holdup $(4.72 \%)$ could not reduce to $0 \%$, and amounts of immobile liquid were still reserved in the pores/voids of ore heaps. Therefore, the liquid hysteresis behavior verified in this paper showed that the mobile liquid flowed out of the unsaturated ore heap, while the immobile liquid was still retained inside [39-41]. This liquid spreading was also quantified by the gray images showing that the proportion of newly retained liquid gradually increased with liquid irrigation, reached the peak value $(14.11 \%)$ at the peak value $(\theta)$, and slightly decreased to $6.87 \%$ at the residual peak value $\left(\theta_{\text {residual }}\right)$ of the drainage process. Except for mechanical flipping and loosening operations, it is unrealistic and hard to adjust PSD or geometric mean diameter of ore feeds in stacked ore heaps [17], thus it is more feasible with lower cost to interrupt and adjust irrigation conditions to promote the liquid retention of ore packed beds.

\subsection{Residual Liquid Holdup Changes in the Irrigation and Drainage Procedure}

It is no doubt that changing irrigation conditions (such as irrigation rate, mode, etc.) can cause disturbances to the liquid retention condition [42]. To further quantify the liquid holdup and better understand the potential effect of the stepwise irrigation condition on hysteresis behavior, the liquid holdup under controlled irrigation and stacking conditions was carefully measured (Figure 3 ).

To better explore the effects of stepwise irrigation on ameliorating liquid retention, consistent stacking and irrigation (superficial flow rate) conditions $(-19.0+13.5 \mathrm{~mm}$, $0.1 \mathrm{~mm} / \mathrm{s}$ ) were used (Figure 3A). The liquid holdup of stepwise irrigation under different geometric particle diameter conditions was also compared (Figure 3B). This illustrated that stepwise irrigation could be divided into two stages distinguished by the $u$ : (1) in the increasing flow rate stage (IFRS, 0-523 $\mathrm{min}$ ), the $u$ stepwise increased from 0.001 to 0.1 $\mathrm{mm} / \mathrm{s}$; (2) in the decreasing flow rate stage (DFRS, 524-800 $\mathrm{min}$ ), the $u$ stepwise decreased from 0.1 to $0.001 \mathrm{~mm} / \mathrm{s}$.

In IFRS, both liquid holdup $(\theta)$ and residual liquid holdup $\left(\theta_{\text {residual }}\right)$ of the ore packed bed improved if a higher $u$ was introduced. However, in DFRS, the $\theta$ gradually decreased, while the $\theta_{\text {residual }}$ roughly kept consistent $(4.52 \%)$ under the stimulation of a lower $u$. Therefore, the $\theta$ was more sensitive to the $u$ (irrigation rate). The $\theta$ tended to decrease, while the $\theta_{\text {residual }}$ could not be disturbed if a lower $u$ was introduced in the unsaturated ore heap. By comparing the peak $\theta$ and $\theta_{\text {residual }}$ of uniform irrigation (Figure 2B) and stepwise irrigation (Figure 3A), the liquid holdup of stepwise irrigation (5.89\%) was much higher than uniform irrigation $(3.25 \%)$, verifying the fact that the ore packed bed could reserve more liquid under stepwise irrigation conditions compared to uniform irrigation. Figure $3 \mathrm{~A}$ shows that, at 0.005 $\mathrm{mm} / \mathrm{s}$, the time to reach a steady state was $50 \mathrm{~min}$ of IFRS, which was much longer than $41 \mathrm{~min}$ of DFRS. This fact was inferred considering that the historical irrigation could shorten the appearance time of preferential flow paths due to the immobile liquid reserved in heaps. 

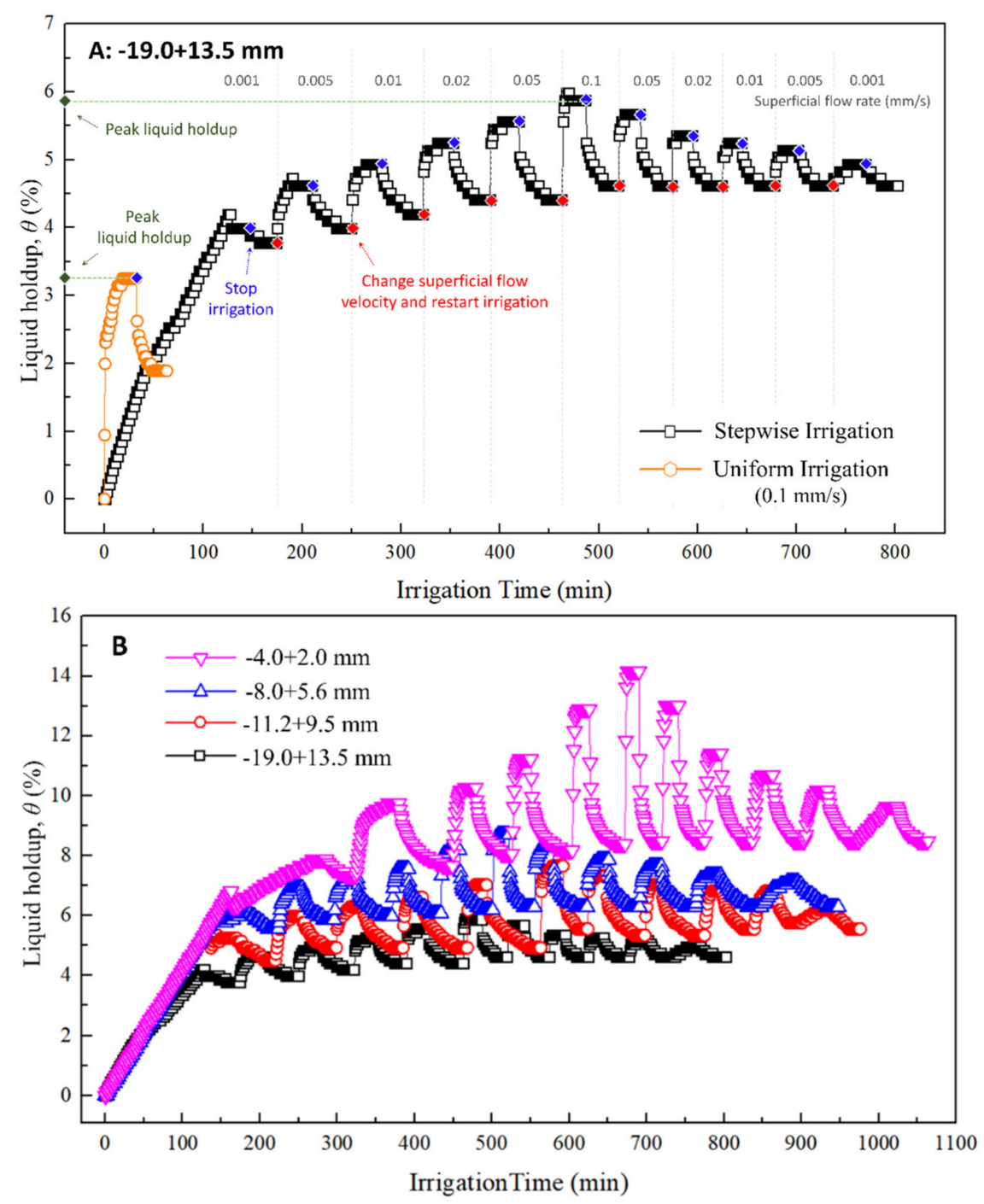

Figure 3. The changes of liquid holdup in a dry ore bed during stepwise irrigation. (A): typical changes of liquid holdup in a dry ore bed $(-19.0+13.5 \mathrm{~mm}),(\mathbf{B})$ : changes of liquid holdup under different particle size conditions.

The liquid holdup of ore heaps is seriously affected by the pore structure, which is tightly related to the geometric mean diameter of packed ore feeds [43-45]. Figure 3B presents the potential effect of geometric mean diameter on liquid holdup under stepwise irrigation conditions. It indicates that the peak residual liquid holdup was negatively related to geometric mean diameter, for instance, the $\theta$ of the $-4.0+2.0 \mathrm{~mm}$ packed bed was higher than $14.0 \%$, which was much larger than the $\theta(5.89 \%)$ of the $-19.0+13.5 \mathrm{~mm}$ packed bed. In DFRS, the $\theta_{\text {residual }}$ of a different packed bed basically kept consistent. This conveys that the $\theta_{\text {residual }}$ was more sensitive to geometric mean diameter, especially at a lower $u$, while the $\theta$ was more sensitive to the $u$. The liquid hysteresis behavior was clearly observed under stepwise irrigation conditions [41]. The $\theta$ of DFRS was slightly higher than the $\theta$ of IFRS at the same $u$. The net difference of liquid holdup indicated that the immobile liquid could not totally flow out and was still retained in intra/inter particle pores if a lower $u$ was introduced [46].

\subsection{Effect of Packed Crushed Ore Diameter on Liquid Retention}

To reveal the potential effect of stepwise irrigation on liquid retention performance, Figure 4 shows the peak weight of liquid retention in the ore heap under different relative porosity conditions. The results showed that the ore heap could reserve more liquid if a 
higher $u$ was introduced. This phenomenon was more obvious when the finer particles or powders occupied a higher percentage in the ore heap. The liquid holdup at steady state was negatively related to geometric mean diameter, while it was positively related to relative porosity. Thus, the well-developed intra-particle pores benefitted from absorbing more liquid [24]. The irrigation period was much longer in the fine-grained ore heap where there was more liquid retained and the liquid spreading was more sufficient. The time to reach the steady state was positively related to geometric mean diameter. For example, the peak weight of reserved liquid ( $135 \mathrm{~g}$ ) was obtained at $676 \mathrm{~min}$ in heaps by fine-grained crushed feeds $(-4.0+2.0 \mathrm{~mm})$, and the lowest weight of liquid $(56 \mathrm{~g})$ was obtained at $471 \mathrm{~min}$ in heaps packed by coarse-grained crushed feeds $(-19.0+13.5 \mathrm{~mm})$.

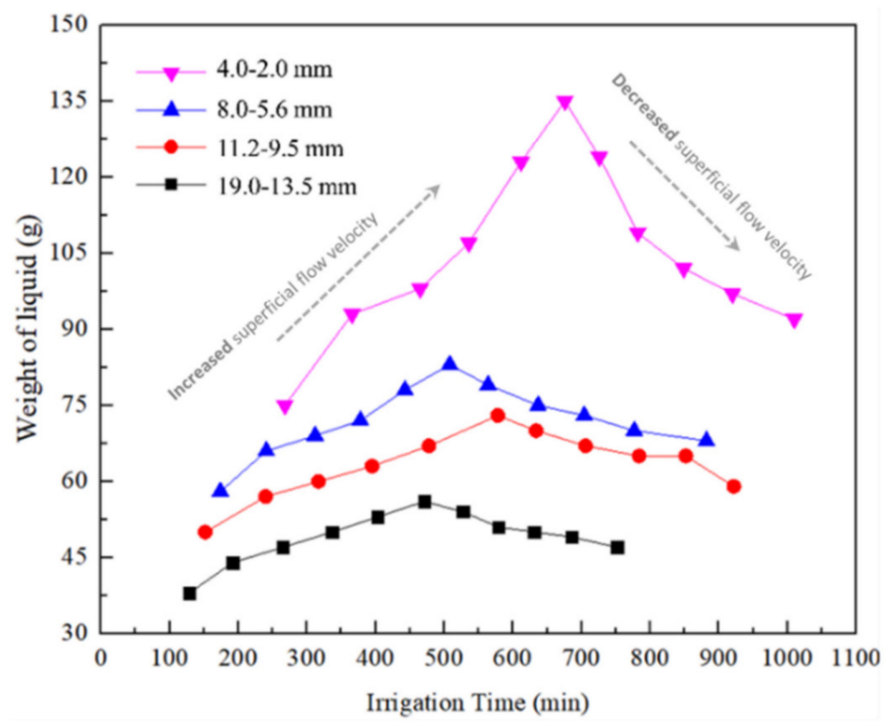

Figure 4. Relationship between irrigation time and weight of liquid retention.

Combined with the stepwise irrigation results, this liquid retention performance under higher $v$ stimulation could be clarified by Figure 5. As Figure 5A shows, large amounts of liquid gathered and transferred along the axis direction below dippers; as a result, the flow paths gradually reached the steady state. This liquid spreading area significantly extended when a higher $u$ was introduced, verifying that the originally existing flow paths rapidly re-formed, and some new flow paths/channels developed at the same time, resulting in desirable liquid retention and a higher steady state liquid holdup $(\theta)$.

Different from the heap packed by glass beads [36], the crushed ore heap was observed to have more liquid due to the well-developed intra-particle pores (Figure 5B). When the $u$ decreased from the higher figure to the initial figure, some new paths that formed under the former higher $u$ condition were still reserved [40]. The liquid hysteresis was inferred considering that the response of the liquid drainage process lagged behind the irrigation amelioration [47]. The amount of immobile liquid could not totally flow out of the heap and was still retained in intra-particle pores (Figure 5C). Hence, it could be conjectured that the immobile liquid mainly played three key roles in the liquid retention and the hysteresis behavior: (1) ameliorating the liquid retention of the unsaturated packed bed; (2) accelerating the appearance of potential flow paths/channels via capillary diffusion; (3) pre-wetting ore feeds and promoting new flow paths when a higher $u$ was introduced [48]

\subsection{Residual Steady State Liquid Holdup Features under Stepwise Irrigation}

To further figure out the residual steady state and better explain the liquid hysteresis behavior that appeared in the drainage process, Figure 6 shows the relationship between the residual steady state liquid holdup value $\left(\theta, \theta_{\text {residual }}\right)$ and the superficial flow rate $(u)$ under stepwise irrigation. 


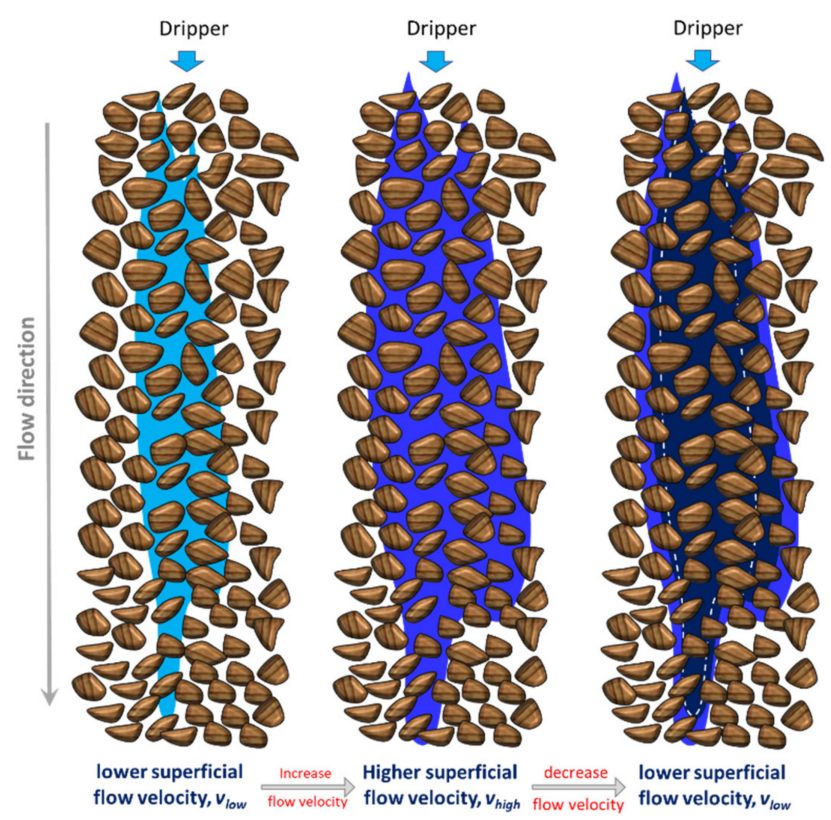

A: Liquid steady state under different superficial flow velocity

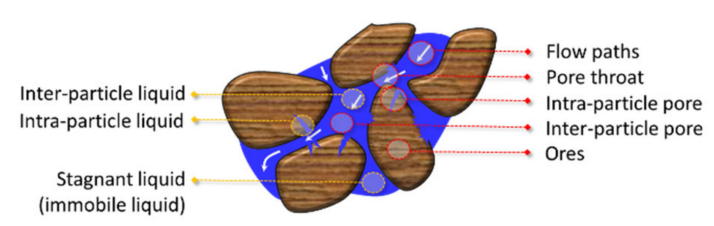

B: Liquid retained in inter-particle and intra-particle pores
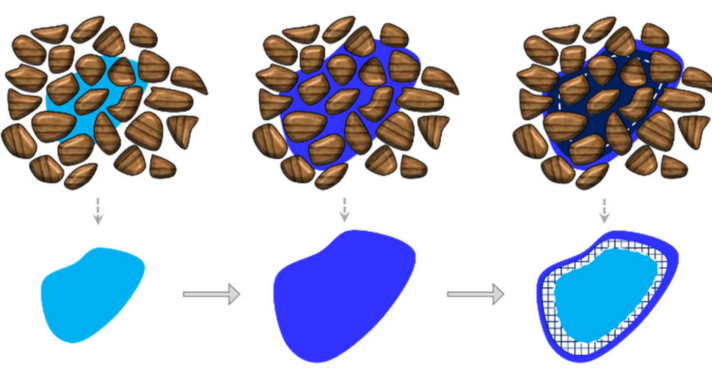

Liquid holdup at lower flow velocity $\left(v_{\text {low }}\right)$
Liquid holdup at higher flow velocity $\left(v_{\text {high }}\right)$
Liquid holdup when $v_{\text {high }}$ decrease to $v_{\text {low }}$
Immobile liquid when $v_{\text {high }}$ decrease to $v_{\text {low }}$

C: Liquid steady regions under different superficial flow velocity

Figure 5. Schematic diagram of liquid holdup and hysteresis behavior in unsaturated packed bed. (A): liquid steady state under different superficial flow rate, (B): liquid retained in inter-particle and intra-particle pores, (C): liquid steady region under different superficial flow rate.
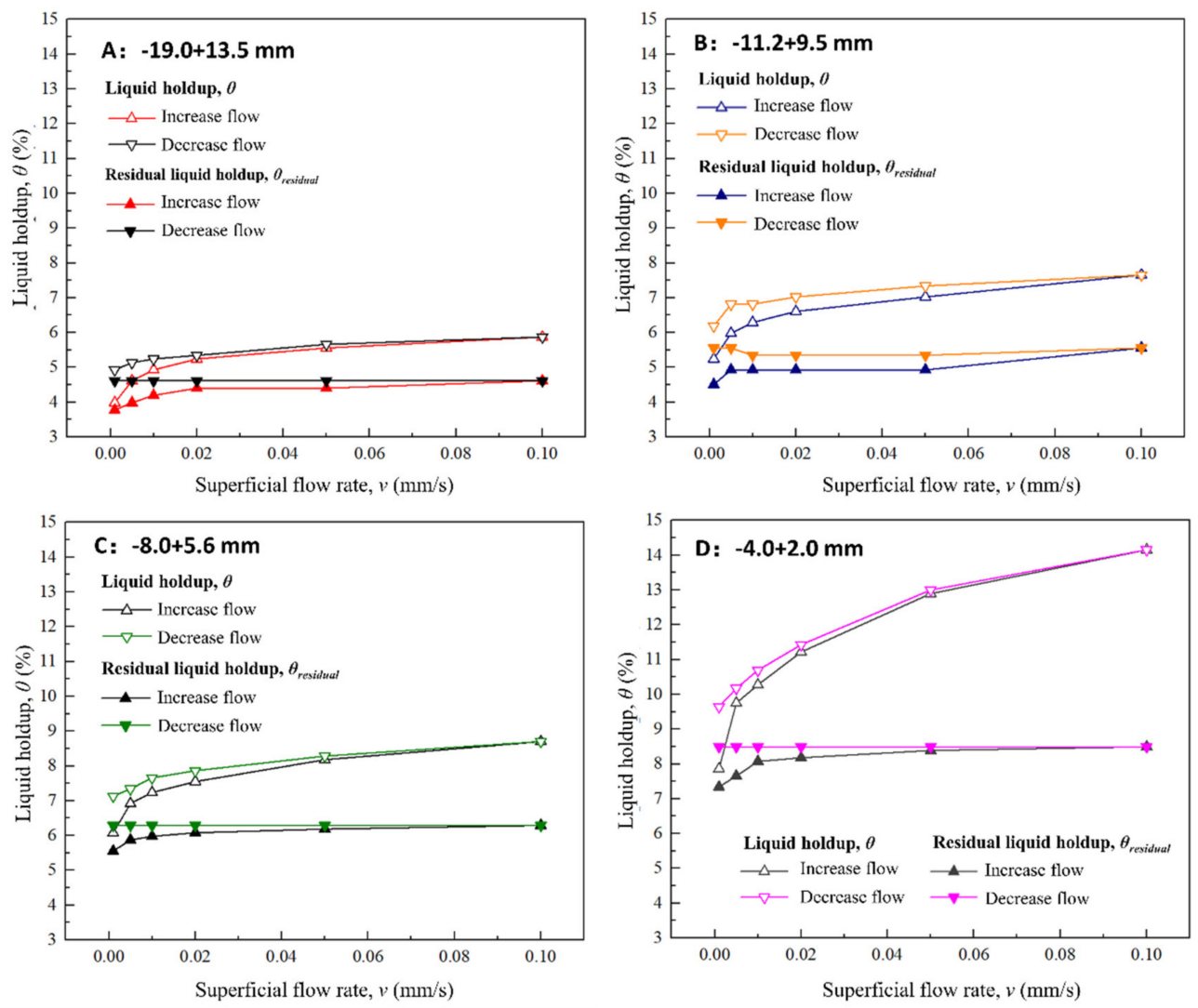

Figure 6. Changes of residual liquid holdup during increase/decrease flow rate arm of stepwise irrigation condition. (A): $-19.0+13.5 \mathrm{~mm} ;(\mathbf{B}):-11.2+9.5 \mathrm{~mm} ;(\mathbf{C}):-8.0+5.6 \mathrm{~mm} ;(\mathbf{D}):-4.0+2.0 \mathrm{~mm}$. 
In IFVS, both the $\theta$ and the $\theta_{\text {residual }}$ increased if a higher $u$ was introduced. For instance, in the $-4.0+2.0 \mathrm{~mm}$ packed bed, $\theta$ increased by $6.29 \%$ and $\theta_{\text {residual }}$ slightly increased by $1.15 \%$ when $u$ was improved from $0.001 \mathrm{~mm} / \mathrm{s}$ to $0.1 \mathrm{~mm} / \mathrm{s}$. This means that even $\theta$ and $\theta_{\text {residual }}$ reached liquid steady state but could still increase if a higher $u$ was introduced. In DFRS, the $\theta$ obviously decreased. At a certain $u$, the $\theta$ of DFRS was slightly higher than the previous value of IFVR; the $\theta_{\text {residual }}$ kept roughly consistent, especially in the fine-grained heap (Figure 6C,D). In the $-4.0+2.0 \mathrm{~mm}$ packed bed, the $\theta$ had a huge decrease of $4.51 \%$ when the $\theta$ decreased from 0.1 to $0.001 \mathrm{~mm} / \mathrm{s}$. At $0.01 \mathrm{~mm} / \mathrm{s}$, the $\theta$ of DFRS had a smaller net increase $(0.42 \%)$ due to liquid hysteresis. The maximum net increase of $\theta$ and $\theta_{\text {residual }}$ was obtained at $0.001 \mathrm{~mm} / \mathrm{s}$. The liquid hysteresis easily performed in the fine-grained heap and lower $u$. This also revealed that $\theta$ was positively sensitive to $u$, but $\theta_{\text {residual }}$ was mainly seriously controlled by heap relative porosity.

\subsection{Effect of Historical Irrigation Condition on Liquid Retention}

To better understand the effect of historical irrigation conditions on liquid retention, the relative liquid holdup $\left(\theta^{\prime}\right.$, defined as the ratio of net liquid holdup and total liquid holdup) was determined. Figure 7 shows the relationship between the $u$ and the $\theta^{\prime}$ of the wetted bed.
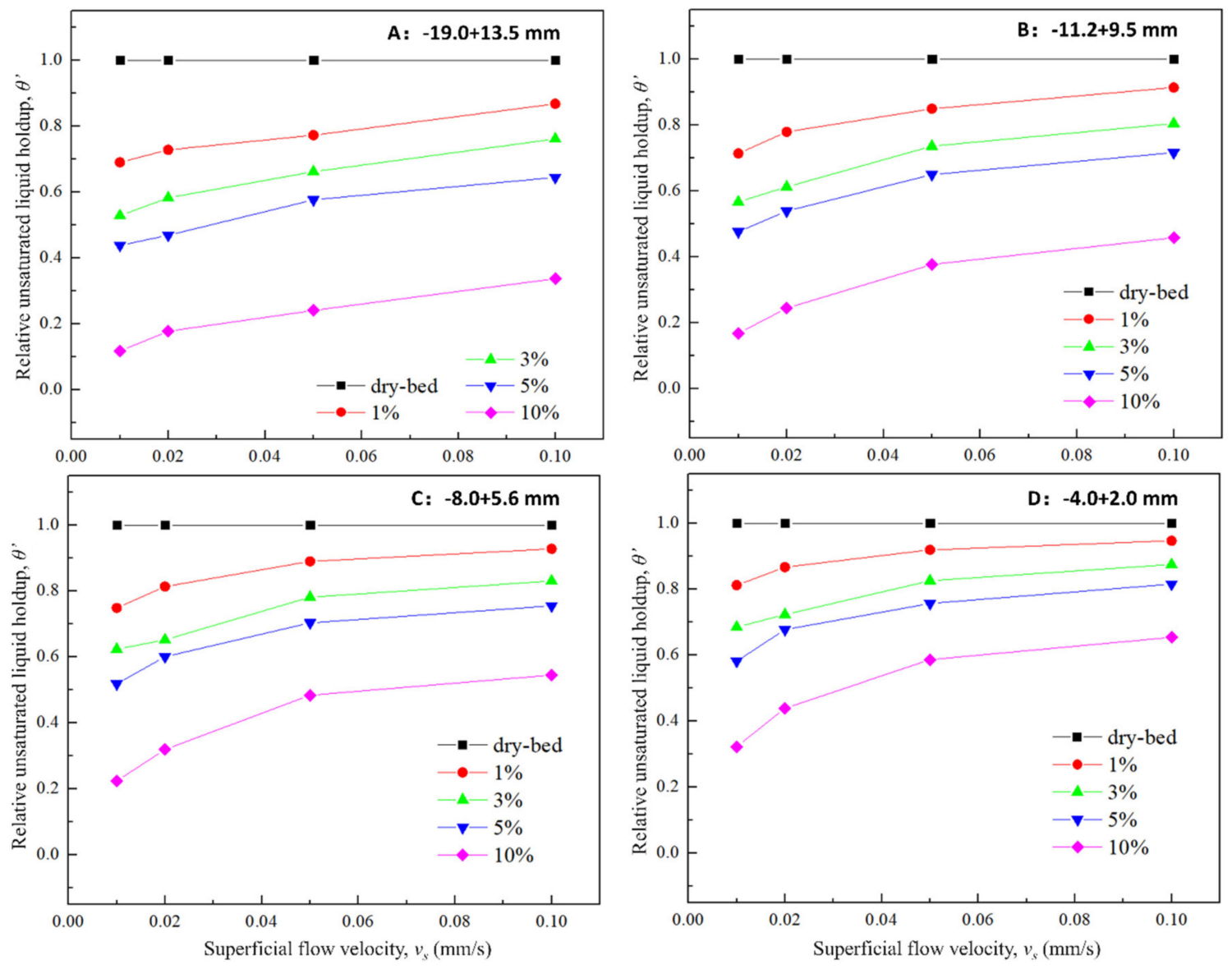

Figure 7. The relationship between superficial flow rate and relative liquid holdup under different geometric mean diameters and initial moisture contents. (A): $-19.0+13.5 \mathrm{~mm}$; (B): $-11.2+9.5 \mathrm{~mm}$; (C): $-8.0+5.6 \mathrm{~mm}$; (D): $-4.0+2.0 \mathrm{~mm}$.

The $\theta^{\prime}$ of the dry bed was consistently 1.0 because the retained liquid was entirely from irrigation. At a certain $u$, the $\theta^{\prime}$ was lower when the ore heap was gradually pre-wetted. Under a lower $u$, the differences of $\theta^{\prime}$ were larger in the bed packed by $-19.0+13.5 \mathrm{~mm}$ feeds. Under a higher $u$, the differences of $\theta^{\prime}$ were smaller, and the $\theta^{\prime}$ value was large in that inter-pore liquid occupied a larger proportion of the total. This also indicates that 
inter-pore liquid in the dry bed occupied a smaller proportion. Because the intra- and the inter- pores co-existed in industrial heaps [49], the heap with well-developed pores could have good potential to store more liquid. The $\theta^{\prime}$ was positively related to $u$ and negatively related to $n^{*}$ and initial moisture content. The peak value was obtained in $0.1 \mathrm{~mm} / \mathrm{s}$ and $-4.0+2.0 \mathrm{~mm}$ conditions. The retained liquid partially filled intra-particle pores via the pre-wetted procedure and directly affected the liquid retention [7].

The peak value of liquid holdup increased when the ore bed was well pre-wetted. This implies that, although the $\theta$ gradually increased with the $u$ under stepwise irrigation, the liquid spread along the pre-existing flow paths and created some new, small rivulets under a higher $u$ stimulation. In the pre-wetting process, the liquid spreading was more developed and uniform, massively eliminating the unsaturated liquid regions. The wetted condition potentially affected inter-pore liquid at the steady state: (1) in the poorly wetted bed $\left(0 \%\right.$ to $5 \%$ initial moisture content), the $\theta^{\prime}$ was much higher than 0.5 , meaning that the liquid spreading was undesirable where the inter-pore liquid occupied a dominated percentage of the total pores; (2) however, in the well pre-wetted bed ( $>10 \%$ initial moisture content), the $\theta^{\prime}$ was higher than 0.5 when the $u$ was higher than $0.05 \mathrm{~mm} / \mathrm{s}$, which was tightly related to fewer unsaturated regions existing in the bed.

\section{Conclusions}

To better understand the effects of stepwise irrigation on liquid retention, the responses of liquid holdup and hysteresis behavior in unsaturated heaps to stepwise irrigation were quantitatively discussed via liquid holdup $(\theta)$, residual liquid holdup $\left(\theta_{\text {residual }}\right)$, superficial flow rate $(u)$, relative porosity $\left(n^{*}\right)$, and relative liquid holdup $\left(\theta^{\prime}\right)$ in this paper.

Based on findings of this paper, it revealed that the intra-particle porosity was more developed in ore beds packed by fine-grained feeds. The preferential flow paths/channels easily appeared and developed in well-wetted heaps with a larger $n^{*}$, resulting in a desirable $\theta$. Once the liquid retention reached steady state at a consistent $u$, the fluid flow paths and channels in the ore heap kept stable and were not affected by a lower $u$ but increased when affected by a higher $u$.

The liquid retention of unsaturated ore packed beds could be ameliorated using stepwise irrigation. These controls of irrigation rate in stepwise irrigation could lead to desirable liquid retention and mass transfer. For instance, the unregular adjustment of the irrigation rate of industrial heaps could disturb preferential flow paths, promote new flow channels growth, and enhance liquid percolation. The drip irrigation with a lower superficial flow rate was suggested to pre-wet ore packed beds and increase the immobile liquid ratio before leaching, resulting in a better solute transport via the liquid film of the leaching interface.

Author Contributions: Conceptualization, L.W.; methodology, L.W.; software, L.W.; validation, L.W. and S.Y.; data curation, L.W., S.Y., and B.D.; writing-original draft preparation, L.W.; writingreview and editing, L.W., S.Y., and B.D.; visualization, L.W.; supervision, S.Y. and L.W.; project administration, L.W. and S.Y.; funding acquisition, S.Y. All authors have read and agreed to the published version of the manuscript.

Funding: This research was funded by the Open Project of Key Laboratory of Green Chemical Engineering Process of Ministry of Education (Grant No. GCP202108), Key Program of National Natural Science Foundation of China (Grant No. 52034001), Funds of key field innovation team of Ministry of Science \& Technology of PRC (Grant No. 2018RA4003), the 111 Project (Grant No. B20041), Shandong Provincial Major Science and Technology Innovation Project, China (Grant No. 2019SDZY05), and the Fundamental Research Funds for the Central Universities (Grant No. FRF-TP-18-003C1).

Data Availability Statement: The data are not publicly available due to confidential reasons.

Acknowledgments: This work was carried out in Hydrometallurgy lab at the University of British Columbia (UBC) and mainly funded the scholarship support of the China Scholarship Council (CSC). We sincerely thank Wenying Liu, David Dreisinger, Zihe Ren, Mohsen Hashemzadeh, Kresimir 
Ljubetic, Ronny Winarko, and Mohamad Mirazimi from UBC for their valuable advice and technical support throughout the work.

Conflicts of Interest: The authors declare no conflict of interest.

\section{References}

1. Petersen, J. Heap leaching as a key technology for recovery of values from low-grade ores-A brief overview. Hydrometallurgy 2016, 165, 206-212. [CrossRef]

2. Yin, S.; Wang, L.; Kabwe, E.; Chen, X.; Yan, R.; An, K.; Zhang, L.; Wu, A. Copper Bioleaching in China: Review and Prospect. Minerals 2018, 8, 32. [CrossRef]

3. Wang, L.; Yin, S.; Wu, A.; Chen, W. Synergetic bioleaching of copper sulfides using mixed microorganisms and its community structure succession. J. Clean. Prod. 2019, 245, 118689. [CrossRef]

4. Watling, H.; Collinson, D.; Li, J.; Mutch, L.; Perrot, F.; Rea, S.; Reith, F.; Watkin, E. Bioleaching of a low-grade copper ore, linking leach chemistry and microbiology. Miner. Eng. 2013, 56, 35-44. [CrossRef]

5. Yin, S.-H.; Wang, L.-M.; Wu, A.-X.; Chen, X.; Yan, R.-F. Research progress in enhanced bioleaching of copper sulfides under the intervention of microbial communities. Int. J. Miner. Met. Mater. 2019, 26, 1337-1350. [CrossRef]

6. Van Staden, P.; Petersen, J. Towards fundamentally based heap leaching scale-up. Miner. Eng. 2021, 168, 106915. [CrossRef]

7. Bouffard, S.C.; West-Sells, P.G. Hydrodynamic behavior of heap leach piles: Influence of testing scale and material properties. Hydrometallurgy 2009, 98, 136-142. [CrossRef]

8. Brierley, C. Biohydrometallurgical prospects. Hydrometallurgy 2010, 104, 324-328. [CrossRef]

9. Yin, S.; Wang, L.; Wu, A.; Free, M.L.; Kabwe, E. Enhancement of copper recovery by acid leaching of high-mud copper oxides: A case study at Yangla Copper Mine, China. J. Clean. Prod. 2018, 202, 321-331. [CrossRef]

10. Wang, L.; Yin, S.; Wu, A. Ore agglomeration behavior and its key controlling factors in heap leaching of low-grade copper minerals. J. Clean. Prod. 2020, 279, 123705. [CrossRef]

11. Yin, S.; Wang, L.; Wu, A.; Kabwe, E.; Chen, X.; Yan, R. Copper recycle from sulfide tailings using combined leaching of ammonia solution and alkaline bacteria. J. Clean. Prod. 2018, 189, 746-753. [CrossRef]

12. Van Staden, P.; Petersen, J. The effects of simulated stacking phenomena on the percolation leaching of crushed ore, Part 1: Segregation. Miner. Eng. 2018, 128, 202-214. [CrossRef]

13. Van Staden, P.; Petersen, J. The effects of simulated stacking phenomena on the percolation leaching of crushed ore, Part 2: Stratification. Miner. Eng. 2018, 131, 216-229. [CrossRef]

14. Wang, L.; Yin, S.; Wu, A.; Chen, W. Effect of stratified stacks on extraction and surface morphology of copper sulfides. Hydrometallurgy 2019, 191, 105226. [CrossRef]

15. Wu, A.; Yin, S.; Yang, B.; Wang, J.; Qiu, G. Study on preferential flow in dump leaching of low-grade ores. Hydrometallurgy 2007, 87, 124-132. [CrossRef]

16. Wu, A.; Yin, S.; Qin, W.; Liu, J.; Qiu, G. The effect of preferential flow on extraction and surface morphology of copper sulphides during heap leaching. Hydrometallurgy 2009, 95, 76-81. [CrossRef]

17. Lima, L.D.A. Liquid axial dispersion and holdup in column leaching. Miner. Eng. 2006, 19, 37-47. [CrossRef]

18. Ilankoon, I.; Neethling, S. Transient liquid holdup and drainage variations in gravity dominated non-porous and porous packed beds. Chem. Eng. Sci. 2014, 116, 398-405. [CrossRef]

19. Solomenko, Z.; Haroun, Y.; Fourati, M.; Larachi, F.; Boyer, C.; Augier, F. Liquid spreading in trickle-bed reactors: Experiments and numerical simulations using Eulerian-Eulerian two-fluid approach. Chem. Eng. Sci. 2015, 126, 698-710. [CrossRef]

20. McBride, D.; Ilankoon, S.; Neethling, S.; Gebhardt, J.; Cross, M. Preferential flow behaviour in unsaturated packed beds and heaps: Incorporating into a CFD model. Hydrometallurgy 2017, 171, 402-411. [CrossRef]

21. Ilankoon, I.; Neethling, S. The effect of particle porosity on liquid holdup in heap leaching. Miner. Eng. 2013, 45, 73-80. [CrossRef]

22. Snyder, V.A. Statistical Hydraulic Conductivity Models and Scaling of Capillary Phenomena in Porous Media. Soil Science Society of America Journal 1996, 60, 771-774. [CrossRef]

23. Fernando, W.A.M.; Ilankoon, I.; Rabbani, A.; Yellishetty, M. Inter-particle fluid flow visualisation of larger packed beds pertaining to heap leaching using X-ray computed tomography imaging. Miner. Eng. 2020, 151, 106334. [CrossRef]

24. Teng, J.; Chu, J.-C.; Liu, C.; Xu, T.; Lien, Y.-F.; Cheng, J.-H.; Huang, S.; Jin, S.; Dang, T.; Zhang, C.; et al. Fluid Dynamics in Microchannels. In Fluid Dynamics, Computational Modeling and Applications; IntechOpen: London, UK, 2012.

25. Fagan, M.A.; Ngoma, I.E.; Chiume, R.A.; Minnaar, S.; Sederman, A.; Johns, M.L.; Harrison, S.T. MRI and gravimetric studies of hydrology in drip irrigated heaps and its effect on the propagation of bioleaching micro-organisms. Hydrometallurgy 2014, 150, 210-221. [CrossRef]

26. Velo, A.; Carvalho, D.; Hamada, M. Liquid distribution and holdup in the random packed column. Flow Meas. Instrum. 2018, 62, 176-185. [CrossRef]

27. Ilankoon, I.; Neethling, S. Inter-Particle liquid spread pertaining to heap leaching using UV fluorescence based image analysis. Hydrometallurgy 2018, 183, 175-185. [CrossRef]

28. Nimmo, J.R. Preferential flow occurs in unsaturated conditions. Hydrol. Process. 2011, 26, 786-789. [CrossRef]

29. Cooper, S.; Peraltaa, C. Stepwise pumping approach to improve free phase light hydrocarbon recovery from unconfined aquifers. J. Contam. Hydrol. 1995, 18, 141-159. [CrossRef] 
30. McBride, D.; Gebhardt, J.; Croft, T.; Cross, M. Modeling the hydrodynamics of heap leaching in sub-zero temperatures. Miner. Eng. 2016, 90, 77-88. [CrossRef]

31. Fernando, W.A.M.; Ilankoon, I.; Chong, M.N.; Syed, T.H. Effects of intermittent liquid addition on heap hydrodynamics. Miner. Eng. 2018, 124, 108-115. [CrossRef]

32. Fan, Y.; Jacob, K.V.; Freireich, B.; Lueptow, R. Segregation of granular materials in bounded heap flow: A review. Powder Technol. 2017, 312, 67-88. [CrossRef]

33. Ilankoon, S.K. Hydrodynamics of Unsaturated Particle Beds Pertaining to Heap Leaching; Imperial College London: London, UK, 2012.

34. Blackmore, S. The Role of Hydrology, Geochemistry and Microbiology in Flow and Solute Transport Through Highly Heterogeneous, Unsaturated Waste Rock at Various Test Scales; The University of British Columbia: Vancouver, BC, Canada, 2015. [CrossRef]

35. Zhang, S.; Liu, W.; Granata, G. Effects of grain size gradation on the porosity of packed heap leach beds. Hydrometallurgy 2018, 179, 238-244. [CrossRef]

36. Ilankoon, S.; Neethling, S. Hysteresis in unsaturated flow in packed beds and heaps. Miner. Eng. 2012, 35, 1-8. [CrossRef]

37. Ghorbani, Y.; Becker, M.; Mainza, A.; Franzidis, J.-P.; Petersen, J. Large particle effects in chemical/biochemical heap leach processes-A review. Miner. Eng. 2011, 24, 1172-1184. [CrossRef]

38. Blackmore, S.; Smith, L.; Mayer, K.U.; Beckie, R.D. Comparison of unsaturated flow and solute transport through waste rock at two experimental scales using temporal moments and numerical modeling. J. Contam. Hydrol. 2014, 171, 49-65. [CrossRef]

39. Mayergoyz, I. Mathematical models of hysteresis. IEEE Trans. Magn. 1986, 22, 603-608. [CrossRef]

40. Extrand, C.W. Contact Angles and Their Hysteresis as a Measure of Liquid-Solid Adhesion. Langmuir 2004, $20,4017-4021$. [CrossRef]

41. Zeidman, B.D.; Lu, N.; Wu, D.T. Hysteresis of liquid adsorption in porous media by coarse-grained Monte Carlo with direct experimental validation. J. Chem. Phys. 2016, 144, 174709. [CrossRef] [PubMed]

42. Wang, L.-M.; Yin, S.-H.; Wu, A.-X. Visualization of flow behavior in ore-segregated packed beds with fine interlayers. Int. J. Miner. Met. Mater. 2020, 27, 900-909. [CrossRef]

43. Yin, S.-H.; Wang, L.-M.; Chen, X.; Wu, A.-X. Effect of ore size and heap porosity on capillary process inside leaching heap. Trans. Nonferr. Met. Soc. China 2016, 26, 835-841. [CrossRef]

44. Nimmo, J.R. Porosity and pore-size distribution. In Encyclopedia of Soils in the Environment; Elsevier: Amsterdam, The Netherlands, 2005; pp. 295-303.

45. Ram, R.; Beiza, L.; Becker, M.; Pownceby, M.; Chen, M.; Yang, Y.; Yang, S.; Petersen, J. Study of the leaching and pore evolution in large particles of a sulfide ore. Hydrometallurgy 2020, 192, 105261. [CrossRef]

46. Robertson, S. Development of an integrated heap leach solution flow and mineral leaching model. Hydrometallurgy 2017, 169, 79-88. [CrossRef]

47. Chung, T.-W. Predictions of moisture removal efficiencies for packed-bed dehumidification systems. Gas Sep. Purif. 1994, 8, 265-268. [CrossRef]

48. Wang, J.-P.; Gallo, E.; François, B.; Gabrieli, F.; Lambert, P. Capillary force and rupture of funicular liquid bridges between three spherical bodies. Powder Technol. 2017, 305, 89-98. [CrossRef]

49. Yin, S.; Wu, A.; Hu, K.; Wang, Y.; Xue, Z. Visualization of flow behavior during bioleaching of waste rock dumps under saturated and unsaturated conditions. Hydrometallurgy 2013, 133, 1-6. [CrossRef] 